\title{
Coarse woody debris in temperate littoral zones: implications for biodiversity, food webs and lake management
}

\author{
Magdalena Czarnecka
}

Received: 9 June 2015/Revised: 16 September 2015/ Accepted: 16 September 2015/Published online: 30 September 2015

(C) The Author(s) 2015. This article is published with open access at Springerlink.com

\begin{abstract}
Coarse woody debris (CWD) represents a relatively stable habitat in many lakes with forested shorelines providing a living place for a wide range of species. The spatial complexity of CWD is recognized as an important factor promoting the abundance, diversity and productivity of littoral biota, mainly by providing shelters and moderating predator-prey interactions. However, little is as yet known on the response of different species to various levels of CWD complexity and the effects of the spatial arrangement of CWD on the connectivity between littoral populations. It is also unclear how CWD decay, which modifies the surface complexity of wood and the quality of food, affects the diversity of wood-associated species and trophic interactions. Further research is also needed to recognize the contribution of littoral wood to carbon sequestration and nutrient fluxes, considering factors affecting the CWD decay rate, such as wood species and environmental conditions. CWD resources are systematically depleted by shoreline development which leads to disruptions in the functioning of lake ecosystems. Attempts at restoring CWD habitat provided ambiguous effects on littoral
\end{abstract}

Handling editor: Katya E. Kovalenko

M. Czarnecka ( $\square)$

Department of Hydrobiology, Faculty of Biology and

Environmental Protection, Nicolaus Copernicus

University, Lwowska 1, 87-100 Torun, Poland

e-mail: mczarn@umk.pl species and therefore better understanding of the role of CWD in lake ecosystems is crucial to the development of successful restoration projects and effective management programmes.

Keywords Habitat complexity - Lake productivity · Predator-prey interactions - Nutrient cycling ·

Xylophagous species

\section{Introduction}

Coarse woody debris (CWD) originating from riparian trees represents a relatively stable habitat in many lakes with forested shorelines (Christensen et al., 1996; Guyette et al., 2002). CWD is usually defined as logs (Fig. 1A), large branches (Fig. 1B), standing dead trees (snags) (Fig. 1C), chunks of wood (fragmented snags and logs), and coarse roots (Fig. 1D) (Harmon et al., 1986) with a diameter $\geq 10 \mathrm{~cm}$ and length $\geq 1 \mathrm{~m}$ (Francis \& Schindler, 2006; Sass et al., 2006; DeBoom \& Wahl, 2013). However, smaller pieces with a diameter $\geq 5 \mathrm{~cm}$ or $0.5 \mathrm{~m}$ in length were also included in this category in some studies (Christensen et al., 1996; Glaz et al., 2009).

Previously, the significance of CWD in the littoral zone was often neglected and poorly studied, as wood usually occupies relatively small patches in comparison to other common habitats, such as macrophytes. However, it has been shown that CWD increases the 
A

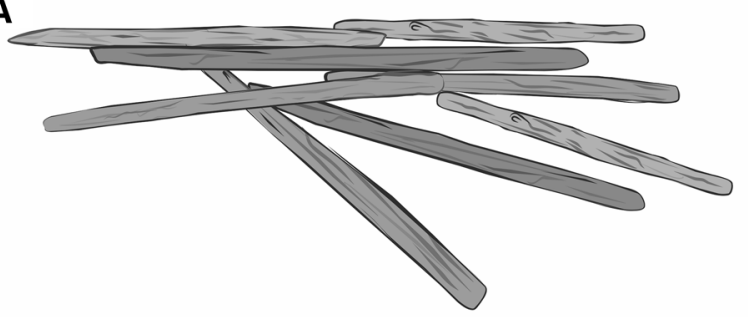

B

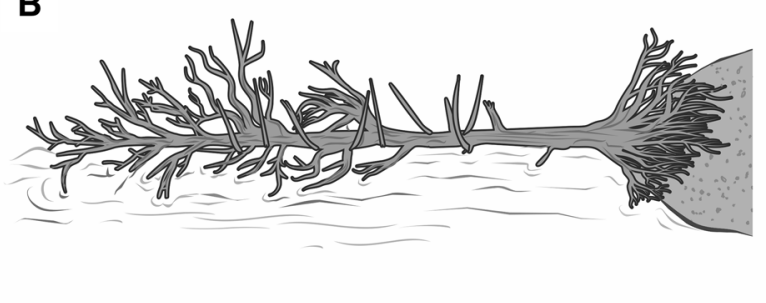

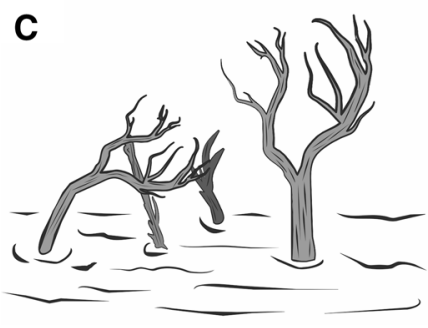

D
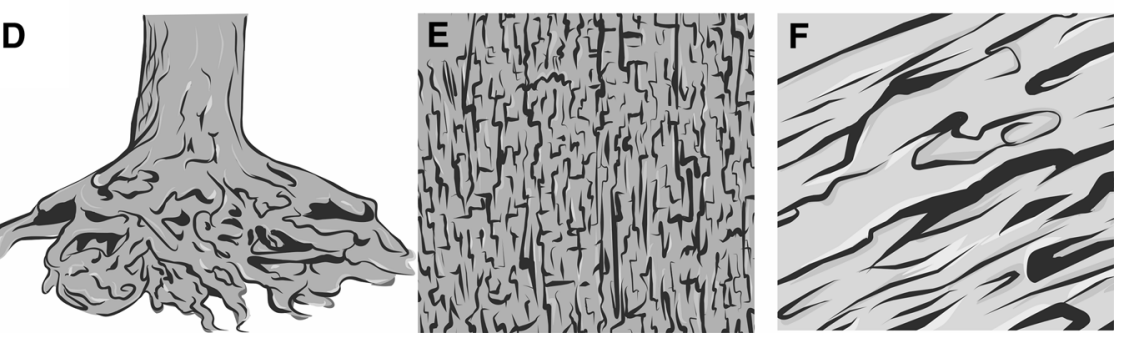

Fig. 1 Various types of CWD in littoral zones. A Logs, B Branched logs, C Snags, D Coarse roots, E Fresh wood with bark on the surface, $\mathbf{F}$ Decayed wood with grooves and pits on the surface

complexity of littoral zones and provides a living place for a wide range of biota (Newbrey et al., 2005; Smokorowski et al., 2006; Glaz et al., 2009), as well as contributing to greater productivity of fish communities (Schindler et al., 2000; Sass et al., 2006). Moreover, CWD as a large carbon sink can be important for carbon sequestration and nutrient fluxes in nearshore areas (Guyette et al., 2002). The interest in CWD in lake ecology has increased in recent years, because it has been noticed that human pressure and shoreline development cause the systematic depletion of CWD stocks and, as a consequence, their loss decreases the abundance and diversity of some species (Sass et al., 2006; Brauns et al., 2011), as well as entailing profound disruptions in lake food webs (Sass et al., 2006; Gaeta et al., 2014). Currently, habitat loss and decreasing biodiversity, which subsequently disturb the functioning of the ecosystem and limit provisioning of services are the main challenges faced by contemporary ecology (Loreau et al., 2001; Dobson et al., 2006). The recognition of the role of CWD in littoral zones and incorporation of such knowledge into more effective environmental management programmes could constrain the adverse effects of human pressure on lakes and improve our understanding of the functions of the ecosystem. Therefore, the present article reviews the contribution of CWD to the maintenance of habitat heterogeneity and biodiversity in the nearshore area of lakes, as well as its significance for cross-boundary nutrient cycling and productivity. I discuss natural and anthropogenic factors influencing input, turnover and distribution of CWD, and potential consequences of the alterations of CWD resources induced by human activity for lake ecosystems and their management. As many CWD functions in littoral zones are still not fully understood, I also highlight gaps in this field.

\section{Dynamics of CWD in littoral zones}

The natural mortality of riparian trees and their damage caused by wind are the main sources of CWD in waters (Harmon et al., 1986). Considerable amounts of dead wood are produced due to natural ecosystem disturbances such as windthrows, occasional fires (Dale et al., 2001; Lindroth et al., 2009; Gennaretti et al., 2014) and increased mortality of trees caused by insect attacks and diseases (Harmon et al., 1986), as well as beaver (Castor sp.) activity (France, 1997; Marburg et al., 2006). Apart from natural agents, particularly logging associated with shoreline development can initially increase CWD inputs by introducing large amounts of debris into the littoral zone (Guyette \& Cole, 1999; Glaz et al., 2009); however, over longer time periods it reduces the stocks 
of wood because of the loss of riparian trees (Christensen et al., 1996; Francis \& Schindler, 2006) and terrestrial CWD, which is very often removed by landowners (Francis \& Schindler, 2006; Marburg et al., 2006).

At the lake scale, the stocks of CWD strongly depend on current local conditions, such as land use, density of riparian vegetation and forest type, but also represent a legacy of the long-term history of past disturbances, both human and natural. Thus, amounts of CWD can significantly vary among lakes, even if they are characterized by a similar degree of lakeshore development (Marburg et al., 2006; Francis \& Schindler, 2006; Gennaretti et al., 2014). For example, densities of CWD in undeveloped lakes without buildings at the shoreline ranged from $42 \mathrm{logs} \mathrm{km}^{-1}$ (Marburg et al., 2009) to $638 \operatorname{logs} \mathrm{km}^{-1}$ (Christensen et al., 1996). Stocks of CWD in littoral zones of developed lakes ranged from $17 \mathrm{logs} \mathrm{km}^{-1}$ (Christensen et al., 1996) to $128 \operatorname{logs} \mathrm{km}^{-1}$ (Francis \& Schindler, 2006), whereas building densities at the shoreline were estimated at 12-25 and 15-47 houses per $\mathrm{km}^{-1}$, respectively. Nevertheless, there are some common patterns of littoral CWD resources and their distribution. For instance, lakes surrounded by forest dominated by larger climax tree species, such as Douglas fir (Pseudotsuga menziesii Franco) and western red cedar (Thuja plicata Donn ex D.Don) can have less CWD than lakes with smaller riparian trees which are more susceptible to disturbances, such as windthrow and beaver activity (Francis \& Schindler, 2006). Amounts of CWD in the littoral zone are also positively correlated with the density of riparian trees (Christensen et al., 1996; Francis \& Schindler, 2006) or riparian CWD available on lake shores (Marburg et al., 2006). Such correlations are very often weaker at particular sites, because buoyant freshly fallen trees are relocated by wind, water currents or ice scour and form relatively stable clusters in parts of a lake that do not usually have high local inputs (Christensen et al., 1996; Guyette \& Cole, 1999; Marburg et al., 2009). Wood accumulates in characteristic locations for a given lake, mainly along shorelines exposed to prevailing winds and currents (Fig. 2A), and on moderate to steep slopes (Marburg et al., 2009). In lakes with steep sloped shorelines the densities of CWD are higher at deeper sites than in shallower bays (Mallory et al., 2000). Greater accumulations of CWD in aquatic systems are also

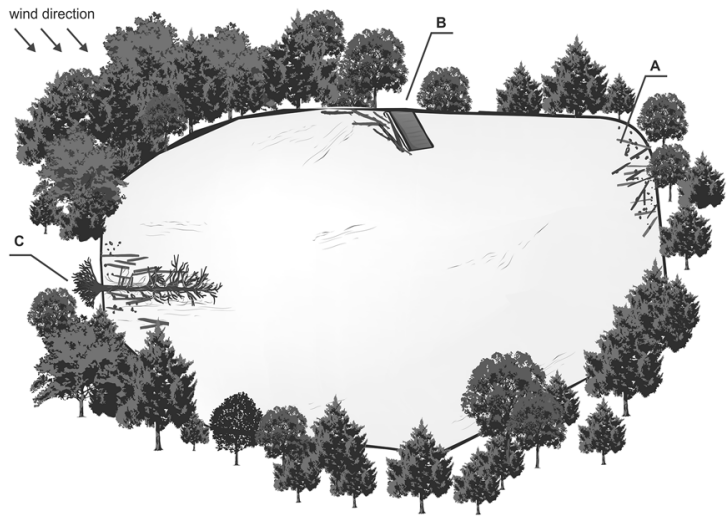

Fig. 2 Distribution patterns of CWD in littoral zones. A Accumulations of logs on the shoreline exposed to prevailing winds, B Accumulations of CWD around jetty, $\mathbf{C}$ Fallen branched tree as a link between terrestrial and littoral zone

observed at the shores of islands or around retentive structures such as standing tree trunks and bridge abutments (Gurnell, 2003) (Fig. 2B).

CWD in lakes is subjected to long-lasting transformation processes which can be measured in centuries (Guyette \& Cole, 1999; Guyette et al., 2002; Gennaretti et al., 2014). Few studies provided evaluations on the residence time of CWD in littoral zones. The persistence time of small twigs was estimated at about 5 years (France, 1997), while the mean residence time of larger logs in some boreal undeveloped lakes ranged from 170 (Glaz et al., 2009) to 386 years (Gennaretti et al., 2014). Little is as yet known on decomposition rates of CWD in lentic ecosystems and the time required for occurrence of different decay stages. Most of our knowledge on CWD degradation in waters is derived from streams. Large pieces of wood introduced to aquatic systems are disintegrated by water movements leading to their breakage and erosion of the external surface (Harmon et al., 1986) which exposes the fresh wood substrate beneath to microbial degradation (Ward \& Aumen, 1986). The initial breakdown of CWD in streams that weakens bark and wood tissue was evaluated at more than 3 years (Braccia \& Batzer, 2008), while erosion rates of wood surfaces were estimated at 0.5-11 mm year ${ }^{-1}$ (Ward \& Aumen, 1986). The physical fragmentation of CWD presumably progresses faster in flowing waters than in lakes where water dynamics are less intense. In both aquatic systems, the decomposition of CWD is highly 
accelerated by wood damage, such as ring shakes, because they allow the direct penetration of water and thus increase the availability of the wood to oxygen and organisms enhancing decay (Harmon et al., 1986; Guyette \& Cole, 1999). The decay rate of CWD is also affected by the properties of wood, such as size and tree species. Smaller branches are more susceptible to degradation, because they offer a higher surface area/ volume ratio supporting higher microbial activity and greater invertebrate density per unit surface area than larger logs (Collier \& Smith, 2003; Spänhoff \& Meyer, 2006). In general, conifers are more resistant to decay because they contain twice as much recalcitrant lignin as deciduous trees (Melillo et al., 1983) and they also differ in the composition of lignin, which is formed from distinct alcohols (Weedon et al., 2009). Moreover, decomposition of conifers can also be limited by the presence of non-structural phenolics such as those contained in resin (Harmon et al., 1986; Weedon et al., 2009). Dense wood such as oak (Quercus robur L.), ash (Fraxinus nigra Marshall), or beech (Fagus sylvatica L.) decompose more slowly than less dense wood such as alder (Alnus glutinosa $\mathrm{L}$. Gaertner), poplar (Populus sp.), or willow (Salix sp.) (Spänhoff \& Meyer, 2006). In addition, tree species containing higher $\mathrm{N}$ concentrations, such as alder (Alnus rugosa Sprengel) or birch (Betula papyrifera Marshall), decompose faster than species with low $\mathrm{N}$ content, such as aspen (Populus tremuloides Michaux), because the presence of nutrients promotes growth of microorganisms causing the breakdown of wood (Melillo et al., 1983).

Apart from physical degradation, CWD is subjected to microbial activity which systematically softens the wood, diminishes its volume (Harmon et al., 1986; Collier \& Smith, 2003) and leads to increased production of fine organic matter (Ward \& Aumen, 1986). Our knowledge on the contribution of microbes to this process in lakes is also scarce. Previous studies conducted in streams have shown that the crucial role in wood degradation is played by fungi which possess unique enzymatic capabilities to digest refractory wood tissue (Harmon et al., 1986; Golladay \& Sinsabaugh, 1991; Tank \& Winterbourn, 1996). CWD decomposition is also enhanced by bacteria. Some of them are capable of degrading lignocellulose (Golladay \& Sinsabaugh, 1991); however, they are mainly involved in the hydrolysis of organic phosphorus and nitrogen compounds (Scholz \& Boon,
1993). Microbial activity strongly depends on oxygen concentration in waters. Wave action and currents in the littoral zone usually provide sufficient amounts of oxygen to stimulate decay; however, this process can be limited when some parts of logs are immersed in water-saturated soils in the nearshore area or in sediments, where anaerobic conditions prevail. Thus, some CWD pieces can even persist in lakes for more than 1500 years and up to five millennia (Gennaretti et al., 2014). The increase in water temperature also enhances microbial metabolism, but on the other hand it can contribute to the reduction of oxygen saturation in water, which slows down the decay process (Ward \& Aumen, 1986; Spänhoff \& Meyer, 2006).

Wood degradation is also caused by feeding activities of many invertebrates. These include scrapers (e.g. mayflies, snails), which accelerate the mineralization of wood due to damaging its external surface by scraping the epixylon, and highly specialized xylophagous species, mining wood or directly feeding on its tissue, such as chironomids, caddisflies and elmids (Pereira et al., 1982). The ecology of xylophages is poorly recognized and their contribution to CWD degradation was examined only in streams. According to previous studies, xylophages use their own enzymes to digest wooden tissue or they use for this purpose sequestered fungal enzymes or symbiotic bacteria and protozoans inhabiting their guts (Anderson et al., 1984; Steedman \& Anderson, 1985; Dudley \& Anderson, 1982).

\section{Effects of CWD on habitat heterogeneity}

Much research underlines the role of CWD in the increasing habitat heterogeneity, which can have important implications for littoral biodiversity and lake food webs (e.g. Smokorowski et al., 2006; Sass et al., 2006a, b; Schneider \& Winemiller, 2008). Clusters of CWD obviously diversify the bottom topography and increase the heterogeneity of littoral zones. Several studies have demonstrated that the heterogeneity increases with increasing CWD density (Fig. 2A) (Schneider \& Winemiller, 2008; Ahrenstorff et al., 2009) as well as at sites with branched submerged trees (Fig. 2C). The branching complexity of CWD was quantified by a special index summing the number of branches present on the bole, which can vary in the littoral zone from 1 (simple logs) to 500 
(complex logs) (Newbrey et al., 2005). On the other hand, branched logs are typical for freshly fallen trees and branches are usually lost due to systematic breakdown of CWD in waters. However, progressing decay of CWD increases its complexity at the microscale, as the structure of initially firm and relatively smooth wood changes due to microbial activity that leads to the formation of many grooves, crevices and cracks on the CWD surface (Pereira et al., 1982; Harmon et al., 1986) (Fig. 1E, F). Therefore, CWD in lakes can be assigned to different decay classes, as firm fresh wood, wood with loose or absent bark or wood with a clearly rotted surface (Smokorowski et al., 2006). The combination of various threedimensional shapes of CWD with different degrees of wood decay provides a mosaic of habitats and a variety of shelters for lake biota that can support diverse wood-associated communities (Newbrey et al., 2005; Smokorowski et al., 2006).

The presence of CWD can also influence the quality and availability of habitats due to modification of hydrodynamics and other environmental conditions in littoral zones. So far, it has been experimentally shown that tree roots and wood pieces provide a physical obstacle to water and dissipate turbulence caused in lakes by wave action, thus increasing the sheltering effect of CWD for invertebrates (Gabel et al., 2008). CWD also increases the sedimentation of suspended particles and contributes to greater accumulation of organic matter in nearshore zones (Francis et al., 2007). Similarly, decaying wood could also locally enhance the heterogeneity of the lake bottom by subsidizing it with coarse and fine sediments, as well as modifying oxygen conditions in the vicinity of CWD. Closely juxtaposed aerobic and anaerobic zones could support different groups of microorganisms, as well as diverse detritivores. However, the impact of CWD on the formation of bottom communities has not been previously examined in lakes.

\section{Effects of CWD on the abundance and diversity of biota}

CWD, in contrast to ephemeral macrophytes, constitutes a stable and persistent substrate capable of maintaining numerous generations of biota (Guyette $\&$ Cole, 1999). Fallen trees anchored at one end on the shoreline and having positive buoyancy in water can be colonized by terrestrial plants and animals, such as insects, mammals, reptiles and amphibians (Guyette \& Cole, 1999) (Fig. 2C). Moreover, newly introduced floating wood that is relocated by currents and waves (Marburg et al., 2009) may transport many species in the shore zone. Therefore, CWD may represent an important link between different habitats; however, these observations were not supported by any systematic studies.

The majority of research dealing with CWD in lakes emphasizes its significance as a habitat supporting abundant fish communities (e.g. Newbrey et al., 2005; Helmus \& Sass, 2008; Schneider \& Winemiller, 2008). Many fish species such as Eurasian perch (Perca fluviatilis L.), roach (Rutilus rutilus L.) (Lewin et al., 2004), yellow perch (Perca flavescens Mitchill), largemouth bass (Micropterus salmoides Lacepède) (Sass et al., 2006a; Helmus \& Sass, 2008; Ahrenstorff et al., 2009; Lawson et al., 2011; Gaeta et al., 2014), bluegill (Lepomis macrochirus Rafinesque) (Barwick et al., 2004) and brook charr (Salvelinus fontinalis Mitchill) (Biro et al., 2008) are associated with CWD in the littoral zone. They seek refuge in wood structures (Lewin et al., 2004; Sass et al., 2006a, b; Biro et al., 2008; Helmus \& Sass, 2008) and food resources (Sass et al., 2006a, 2012). Moreover, some fish taxa, such as yellow perch (Sass et al., 2006a; Helmus \& Sass, 2008) and largemouth bass (Lawson et al., 2011) are known to utilize CWD as a spawning habitat. The structure of fish communities is strongly affected by the spatial complexity of CWD. It has been shown that the abundance and diversity of fish are significantly higher in CWD than in open water habitat (Sass et al., 2006b). Similarly, an increase in the fish abundance and species richness is observed in patches with a high density of CWD (Schneider \& Winemiller, 2008) and among logs with a branching index higher than 45 (Newbrey et al., 2005). Fish in areas with CWD exhibit a lower tendency to migration (Lewin et al., 2004; Ahrenstorff et al., 2009), because wood provides shelters against predators and this particularly attracts juveniles and small-bodied species (Lewin et al., 2004; Sass et al., 2006a, b; Biro et al., 2008; Helmus \& Sass, 2008). Patches with high CWD densities also provide more abundant and diversified food resources for piscivorous and benthivorous fish than sites poor in wood (Sass et al., 2006a, b, 2012). 
Wooden $\operatorname{logs}$ and tree roots also create a hard, stable platform for attachment which is available for colonization all year round by epixylon consisting of algae (Bowen et al., 1998; Vadeboncoeur et al., 2006), as well as rich invertebrate communities (Smokorowski et al., 2006; Glaz et al., 2009; Brauns et al., 2011). Invertebrates are usually facultative users of CWD (France, 1997) and, according to experimental studies, they utilize wood as a place for oviposition, pupation, case-building and emergence (Anderson et al., 1984), as well as refuge (Everett \& Ruiz, 1993; Czarnecka et al., 2014) and source of food (Eggert \& Wallace, 2007). Wood-associated invertebrates also benefit from the spatial complexity of CWD, as their densities are usually significantly greater on wood than on adjacent sediments (Lewin et al., 2004; Smokorowski et al., 2006). They are also more numerous and diverse at sites with high wood abundances (Schneider \& Winemiller, 2008). However, it is not clear if invertebrate communities respond more to the mesoscale complexity of CWD or whether their structure is rather determined by differences in the microstructure of the wood surface. Several experiments have demonstrated that decayed CWD with pits and grooves can be particularly favourable for these small-bodied organisms, because in comparison to firm fresh wood it offers greater availability of shelters protecting against predators with different body size (Czarnecka et al., 2014) and rich food resources, such as epixylic biofilm (Bowen et al., 1998) and fine particulate organic matter accumulated on the rugged surface (O'Connor, 1991). Results obtained from lakes also demonstrate that various forms of natural CWD can produce variable effects on the structure of wood-associated communities. Abundances and diversities of invertebrates as well as chlorophyll $a$ concentrations on littoral wood with loose bark and wood with a clearly rotted surface are significantly higher than on fresh wood (Smokorowski et al., 2006). The interacting effects of increasing habitat complexity, as well as changes in the quality of food resources with progressing decay of CWD can also induce successional shifts in the composition of epixylic communities, as has been shown in streams (Golladay \& Webster, 1998; Collier \& Halliday, 2000). Usually, highly degraded wood supports more species specifically associated with CWD, such as xylophages, which benefit from greater availability of wooden tissue and nutrients released during decomposition (Anderson et al., 1984). Although no detailed research in lakes has been made, an experimental study by Bowen et al. (1998) has revealed the domination of collectors and scrapers (Chironomidae, Oligochaeta and Heptageniidae $<$ Ephemeroptera $>$ ), as well as high densities of predators (mainly Polycentropodidae $<$ Trichoptera $>$ ) on fresh wood with abundant biofilm cover, while with advancing decay of the wood, an increase in numbers of xylophagous Elmidae (Coleoptera) and Stenochironomus sp. was noted (Bowen et al., 1998). Xylophages recorded in other studies were represented in lakes by the caddisfly genus Lype sp. (Psychomyiidae) (Brauns et al., 2007, 2011) and wood-mining chironomids: Glyptotendipes sp. and Dicrotendipes sp. (Czarnecka et al., 2014); they colonized CWD in different decay status. Typically, CWD is also inhabited by fungi and bacteria, which can comprise even up to $90 \%$ of the microbial biomass colonizing wood (Golladay \& Sinsabaugh, 1991; Tank $\&$ Winterbourn, 1996). Although these wood-specific species determine the peculiarity of epixylic communities and play an essential role in CWD degradation and nutrient cycling in the littoral zone, our knowledge on their taxonomic composition and contribution to the diversity of epixylon is scarce.

Some studies indicated that environmental conditions could also contribute to the variability of woodassociated communities. For instance, it has been shown that differences in the concentration of nutrients ( $\mathrm{N}$ and $\mathrm{P}$ ) in lake waters affect the abundance of epixylic algae (Vadeboncoeur \& Lodge, 2000). Moreover, algal biomass usually decreases with increasing depth and, as a consequence, the abundance, number of taxa and diversity of invertebrates on CWD at deeper sites $(>1 \mathrm{~m})$ is also significantly lower (Glaz et al., 2009). Epixylic communities are also subjected to seasonal changes. The abundance of algae is highest in spring and declines in summer, probably due to algal senescence and intense grazing by invertebrates, whereas densities and species richness of invertebrates is two-fold greater in autumn than in spring and summer, when in temperate zones the peak of emergence of many insects is noted (Glaz et al., 2009). Similarly, the structure of littoral fish communities using CWD habitat may be affected by seasons, but this issue has not been previously examined. Nevertheless, the recognition of the variability in the abundance and diversity of fish in CWD between 
different seasons could be helpful in the determination of the significance of wood for this biota in periods preceding the development of macrophytes.

\section{Nutrient cycling and productivity in CWD habitat}

CWD in aquatic systems represents a cross-boundary subsidy and a large pool of nutrients (Harmon et al., 1986; Ward \& Aumen, 1986); however, there has been surprisingly little interest in examining the significance of CWD to nutrient cycling in lakes. Few studies considered the potential contribution of CWD to carbon sequestration, as wood is primarily a carbon source and sink. The mean time from carbon assimilation by a living tree to carbon loss by littoral wood was estimated at $362-443$ years. This is about $9-80$ times greater than in terrestrial environments, because degradation of wood in water is limited by lower oxygen concentrations (Guyette \& Cole, 1999; Guyette et al., 2002). Therefore, based on a study conducted in Ontario, it has been argued that even though littoral zones constitute $1.3 \%$ of the total basin area, they may sequester carbon more than six times longer than the landscape as a whole (Guyette et al., 2002). On the other hand, another study has shown that the contribution of CWD to carbon sequestration is negligible, as amounts of carbon stored in littoral CWD represented less than $0.05 \%$ of the total amount of carbon sequestered in boreal forest on a per area basis, despite the fact that lakes occupied $25 \%$ of the studied area and the mean residence time of pieces of CWD was estimated at 535 years (Gennaretti et al., 2014). Therefore, considering regional differences and complex interactions among CWD stocks and factors affecting their decay rate, such as wood species and environmental conditions, more systematic studies are still needed to clarify the relationships between carbon sequestration and lake CWD.

Little is known either about food web interactions in the littoral CWD, particularly in respect of the susceptibility of wood to degradation, which determines the complexity of this habitat and availability of food resources. Studies conducted in streams have shown that fresh wood is poor in nutrients such as $\mathrm{N}, \mathrm{P}$, and $\mathrm{K}$; however, as decay proceeds, their concentrations significantly increase due to microbial respiration. The nitrogen content can also increase via $\mathrm{N}$ fixation, which is performed in decaying wood by microbes with active nitrogenase, such as obligate anaerobes genus Klebsiella and Enterobacter (Harmon et al., 1986). Epixylic fungi and bacteria derive certain amounts of $\mathrm{N}$ and $\mathrm{P}$ directly from wood (Tank \& Dodds, 2003), whereas algae benefit from carbon released during degradation of wooden tissue (Sinsabaugh et al., 1991). Nutrients liberated from CWD can also be directly used by epixylic invertebrates, including facultative xylophages (Dudley \& Anderson, 1982; Steedman \& Anderson, 1985; Harmon et al., 1986); however, invertebrate consumers are mostly subsidized by biomass produced by epixylic biofilm. Some experiments have shown that wood biofilm was readily assimilated by consumers, and its abundance (particularly in terms of algae) was negatively correlated with invertebrate numbers (Spänhoff et al., 2006; Eggert \& Wallace, 2007). In lakes such correlations between chlorophyll $a$ content and grazer densities on CWD were not found (Smokorowski et al., 2006; Glaz et al., 2009), but a seasonal decline in chlorophyll concentrations reported in summer by Glaz et al. (2009) may suggest that invertebrates fed on algae. Other experiments have revealed that macroinvertebrates also feed on epixylic bacteria and fungi (Eggert \& Wallace, 2007), and extracellular polysaccharides produced by bacteria can be an important source of carbon for detritivores (Golladay \& Sinsabaugh, 1991; Couch \& Meyer, 1992), which are otherwise subsidized by organic matter originating from decaying wood (Ward \& Aumen, 1986) or accumulated on CWD due to water movements and increased sedimentation (O'Connor, 1991).

More is known about the contribution of woodassociated communities to the productivity of the littoral zone. Vadeboncoeur \& Lodge (2000) and Vadeboncoeur et al. (2006) compared the area-specific algal production on CWD and littoral sediments and estimated that the former is 5-10 times lower than that observed in algal communities living on the sediment surface (epipelon). Moreover, the chlorophyll content $\left(\mathrm{mg} \mathrm{m}^{-2}\right.$ ) on CWD is 5-100 times lower than that recorded for lake sediments. The primary production of epixylon is probably limited by the inability of epixylic algae to derive $\mathrm{N}$ and $\mathrm{P}$ directly from wood, in contrast to epipelon, which colonizes sediments rich in nutrients. Contrary to primary producers, the areaspecific productivity of invertebrates $\left(\mathrm{mg} \mathrm{m}^{-2}\right)$ is significantly greater on CWD than on adjacent sediments (Smokorowski et al., 2006), probably due to 
increased habitat complexity and greater availability of shelters on CWD (Everett \& Ruiz, 1993; Czarnecka et al., 2014). Similarly, a 30-50\% higher biomass of invertebrates is also recorded on more complex decayed CWD than on fresh wood (Smokorowski et al., 2006; Czarnecka et al., 2014). However, the extrapolation of the results obtained to a whole-lake scale shows that the contribution of epixylic algae and invertebrates to benthic production is rather locally important, as CWD in the littoral zone occupies a relatively small area in comparison to open sediments (Smokorowski et al., 2006; Vadeboncoeur et al., 2006).

The presence of CWD is more relevant to the productivity and growth of littoral fish, which are positively influenced by the spatial complexity of this habitat (Schindler et al., 2000; Sass et al., 2006a; Gaeta et al., 2014). In general, complex CWD structures increase the survivorship of fish by providing spawning habitats and abundant food resources (Sass et al., 2006a), as well as stabilizing predator-prey interactions by causing visual interference that prevents predators from seeing potential prey (Everett \& Ruiz, 1993; Sass et al., 2006b). However, the behavioural responses of predators and their prey to the complexity of CWD habitat are species-specific (Everett \& Ruiz, 1993; DeBoom \& Wahl, 2013). For instance, at increased density or branching complexity of CWD, high foraging efficiencies and growth rates are exhibited by ambush predators, such as muskellunge (Esox masquinongy Mitchill), and predators with flexible feeding behaviour, such as largemouth bass, which are able to change their foraging strategy from cruising to sit-and-wait and thus maintain high consumption rates at a reduced activity (Ahrenstorff et al., 2009; DeBoom \& Wahl, 2013). On the other hand, the vulnerability of prey species can also change at different levels of CWD complexity due to modification of their avoidance behaviour. It has been experimentally shown that some fish such as golden shiners (Notemigonus crysoleucas Mitchill) increase the number of independent shoals and isolated individuals in complex branched logs and thus become more vulnerable to bass predation, whereas other species such as bluegill show such behaviour at low and moderate CWD complexity (DeBoom \& Wahl, 2013). The presence of CWD also influences the susceptibility of invertebrate prey to fish predation and the foraging success is dependent on the predator species
(Everett \& Ruiz, 1993). The effects of CWD microstructure on the interactions between invertebrates and predatory fish are more complex and represent a trade-off between different prey density and varied availability of refuge on fresh and decayed wood, as well as species-specific abilities of invertebrates to find shelter in CWD (Czarnecka et al., 2014). Therefore, different levels of CWD complexity combined with species-specific traits of predatory fish and their prey could lead to a more diversified use of prey resources and can exert multiple effects on predatorprey interactions and the lake food web.

\section{Human impact on CWD resources}

In recent years, a systematic decline in CWD stocks in lakes has been observed, mainly due to shoreline development (Christensen et al., 1996; Francis \& Schindler, 2006; Marburg et al., 2006), which often includes deforestation and thus disturbs the inflow of CWD to the aquatic environment (Guyette et al., 2002; Francis \& Schindler, 2006; Marburg et al., 2006). CWD is also intentionally removed from lakes, because it is often considered as an obstacle for navigation and recreational activity (Jennings et al., 2003; Marburg et al., 2006). Moreover, residents may affect the CWD turnover due to modification of the structure of riparian forests as well as the size distribution of terrestrial CWD, because they preferentially leave larger riparian trees on lakeshore properties for aesthetic purposes and introduce nonnative, ornamental species which differ in litterfall patterns in comparison to native trees (Francis \& Schindler, 2006). The direct loss of littoral CWD can also be caused by climate-driven changes, as has been shown in an oligotrophic Wisconsin lake, where a multiyear drought drastically declined the water level (over $1.1 \mathrm{~m}$ ). As a consequence, more than $75 \%$ of the previously submerged CWD in the littoral zone was stranded above the waterline and lost for fish and prey production (Gaeta et al., 2014).

So far, the effects of CWD loss on the abundance and diversity of littoral communities and on lake food webs have been documented by several studies. The decrease in CWD stocks had the most severe implications for fish, resulting in their significantly lower growth rate (Schindler et al., 2000; Ahrenstorff et al., 2009; Gaeta et al., 2014), as well as contributing to the 
collapse of some fish populations (Gaeta et al., 2014). The experimental removal of $70 \%$ of littoral wood from a small oligotrophic lake revealed the mechanism of such changes. Within 2 years after the manipulation, a significant decline in the dominant yellow perch population was observed, resulting from the loss of spawning and refuge habitat. The decrease in the perch abundance induced profound alterations in the whole-lake food web, as the diet of a top piscivore, the largemouth bass, which previously preyed upon perch, shifted towards less energetically favourable terrestrial prey, benthic invertebrates and smaller fish prey. Thus, this inhibited the growth rate of bass (Sass et al., 2006a; Helmus \& Sass, 2008). The lower growth of this species is also caused by changes in its behaviour, as bass in areas poor in wood exhibit more cost-effective active searching and lower consumption rates (Ahrenstorff et al., 2009). It should be emphasized that the response of fish to the absence or decreased density/complexity of CWD is speciesspecific (DeBoom \& Wahl, 2013); therefore more detailed studies with different fish species are needed to clarify the potential effects of changes in CWD resources on fish communities. There is also a need to define a threshold at which the loss of CWD stocks or decreased CWD complexity negatively affects fish assemblages. Moreover, it should be considered that the impact of decreased CWD resources on littoral fish can be masked by other factors, such as fishing, harvest, the presence/absence of macrophytes, lake productivity and food web complexity (Roth et al., 2007).

The effects of CWD loss on epixylic communities are ambiguous. For instance, the extensive, wholelake removal of CWD did not significantly influence the abundance, diversity and biomass of resident macroinvertebrates, at least in the short term, probably due to a relatively small proportion of removed biota from the nearshore area (Smokorowski et al., 2006; Helmus \& Sass, 2008). The removal of CWD did not result either in a significant decrease in the biomass of benthic algae (Smokorowski et al., 2006). On the other hand, in zones poor in CWD the lower abundance and diversity of macroinvertebrates has been observed in the fish diet (Sass et al., 2006a, 2012). Another study also suggested the deterioration of food and habitat conditions for benthic detritivores in the littoral zone with low CWD densities, as sediments rich in organic matter were moved into deeper parts of a lake (Francis et al., 2007). The adverse impact of the decreased CWD stocks on invertebrates could be intensified in combination with the removal of riparian trees (Brauns et al. 2007, 2011). Their depletion leads to the disruption of the link between the lake and the riparian zone, reduces inputs of coarse organic matter (Francis et al., 2007) and enhances inflows of fine sediments to lakes (Jennings et al., 2003). This results in lower macroinvertebrate consumer richness and food web complexity in developed lakes, due to loss of or decline in some functional groups such as shredders and xylophages, and may disturb detrital energy pathways and organic matter transformation in the littoral zone (Brauns et al., 2007; Francis et al., 2007; Brauns et al., 2011).

Changes in the CWD input and its temporal dynamics induced by human activity can also alter nutrient cycling and carbon sequestration in lake ecosystems, but effects of such anthropogenic impact on littoral food webs are largely unknown (Guyette et al., 2002). The global warming scenario assumes an increase in mean water temperatures that can enhance microbial activity and accelerate decomposition rates of organic matter in aquatic environments (Carpenter et al., 2011). On the other hand, natural events that affected CWD inputs to the aquatic environment have previously been episodic and relatively seldom, but in the last decades, an intensification of such phenomena has been observed. Climate change has increased the frequency, intensity and duration of fire, drought, windstorms, insect and pathogen outbreaks in forests (Dale et al., 2001; Lindroth et al., 2009). Such extreme events produce enormous amounts of debris; however, little is as yet known about how they affect the CWD stocks and nutrient fluxes in aquatic systems.

\section{Implications for conservation and management}

As the presence of CWD in the littoral zone underpins many ecosystem functions (Table 1), its loss can have severe consequences for the biodiversity of littoral communities and food webs, particularly in oligotrophic or highly eutrophic lakes, where macrophytes are generally scarce. The recovery of CWD resources is a long-lasting process, because the natural recruitment rate of CWD is very low. Christensen et al. (1996) estimated that in temperate lakes lost CWD could be replaced only after 200 years, given the input 
Table 1 The effects of the presence of CWD in littoral zones on ecosystem functions

\begin{tabular}{|c|c|c|}
\hline Ecosystem function & \multicolumn{2}{|c|}{ Effects of the presence of CWD } \\
\hline Climate regulation & \multicolumn{2}{|c|}{ Contribution to carbon sequestration $(1,2)$} \\
\hline Disturbance regulation & $\begin{array}{l}\text { Sediment retention in the lit } \\
\text { Bank protection against eros } \\
\text { Reduction in shear stress an }\end{array}$ & d disturbances (5) \\
\hline Nutrient regulation & $\begin{array}{l}\text { Cross-boundary subsidy and } \\
\text { Contribution to carbon seque } \\
\text { Contribution to the producti }\end{array}$ & $\begin{array}{l}\text { of nutrients }(1,2,13) \\
(6,7,8) \text {, invertebrates }(7,9) \text { and fish }(10,11,12)\end{array}$ \\
\hline Supporting habitat & \multicolumn{2}{|c|}{$\begin{array}{l}\text { Habitat for terrestrial plants and animals }(13) \text {; algae }(7,8,14,15) \text {; invertebrates }(7,9,14,15 \text {, } \\
16,21,23) \text {; fish }(10,11,12,17-25) \\
\text { Spawning habitat }(11,23,25) \\
\text { Transport of species by floating CWD across littoral zones (13) }\end{array}$} \\
\hline Food & $\begin{array}{l}\text { Decaying wood as a source } \\
\text { Consumption of epixylic alg } \\
\text { Consumption of epixylic bac } \\
\text { Invertebrates colonizing CW }\end{array}$ & $\begin{array}{l}\text { atter for detritivores }(4) \\
\text { brates }(26) \\
\text { gi by invertebrates }(26) \\
\text { base for fish }(9,11,18,27)\end{array}$ \\
\hline Genetic resources & $\begin{array}{l}\text { Sites with high densities of } \\
\text { Greater diversity of fish amc } \\
\text { High diversity of invertebrat } \\
\text { Domination of xylophagous }\end{array}$ & $\begin{array}{l}\text { e diversity of invertebrates and fish }(21) \\
\text { aplex branched CWD (19) } \\
\text { d wood }(7,14) \\
\text { yed wood (14) }\end{array}$ \\
\hline Provision of shelters & \multicolumn{2}{|c|}{ Refuge for invertebrates (9) and fish $(11,18,20,22,23)$} \\
\hline (1) Guyette et al. (2002) & (11) Sass et al. (2006a) & (21) Schneider \& Winemiller (2008) \\
\hline (2) Gennaretti et al. (2014) & (12) Gaeta et al. (2014) & (22) Biro et al. (2008) \\
\hline (3) Jennings et al. (2003) & (13) Guyette \& Cole (1999) & (23) Helmus \& Sass (2008) \\
\hline (4) Francis et al. (2007) & (14) Bowen et al. (1998) & (24) Ahrenstorff et al. (2009) \\
\hline (5) Gaeta et al. (2014) & (15) Glaz et al. (2009) & (25) Lawson et al. (2011) \\
\hline (6) Vadeboncoeur \& Lodge (2000) & (16) France (1997) & (26) Eggert \& Wallace (2007)* \\
\hline (7) Smokorowski et al. (2006) & (17) Barwick et al. (2004) & (27) Sass et al. (2012) \\
\hline (8) Vadeboncoeur et al. (2006) & (18) Lewin et al. (2004) & (*) experimental study \\
\hline (9) Czarnecka et al. (2014)* & (19) Newbrey et al. (2005) & \\
\hline (10) Schindler et al. (2000) & (20) Sass et al. (2006b) & \\
\hline
\end{tabular}

Experimental results are indicated by asterisk

rate at $2.52 \operatorname{logs} \mathrm{ha}^{-1}$ year $^{-1}$ and conservative assumptions of no decomposition and a $10 \mathrm{~m}$ width of riparian forest contribution to CWD inputs. Hence, CWD stocks could be recovered by the intentional introduction of wood to the littoral zone. Particularly beneficial could be provision of greater densities of CWD or branched logs, which usually support abundant and diverse communities (Newbrey et al., 2005; Schneider \& Winemiller, 2008). In lakes such solutions are hardly used and, so far, there has been surprisingly little interest in a more systematic examination of the colonization pattern of CWD by wood- associated communities in lake ecosystems. Nevertheless, some results suggest that positive changes in the structure of littoral populations could be observed only after a longer period following CWD introduction, which is actually difficult to define. Sass et al. (2012) have demonstrated that the whole-lake provision of CWD had no significant influence on the fish abundance, their size-structure and growth within four years of observations, even though the diversity of macroinvertebrate prey increased. Also Bowen et al. (1998) observed that even after a 1-year colonization time of experimentally introduced fresh branches the 
concentration of chlorophyll $a$ on their surfaces was almost three times lower than on CWD submerged in lakes. Similarly, the restoration of epixylic taxa colonizing highly decayed wood could be expected in the longer term. Experiments conducted in streams, where the addition of CWD has been widely applied, did not provide satisfactory results either. The introduced wood was often rapidly colonized by algae and invertebrates (Drury \& Kelso, 2000; Bond et al., 2006), and attracted many fish species (Flebbe, 1999; Howell et al., 2012); however, in many studies the enhancement of habitat heterogeneity did not significantly increase the biodiversity of invertebrates and fish (Palmer et al., 2010). The reasons for the failure of these restoration projects still remain unclear; however, the review by Palmer et al. (2010) suggests that different biota can respond variously to increased habitat heterogeneity. Moreover, other factors such as water quality, connectivity between habitats and riparian conditions can strongly determine the final effects of habitat manipulation.

As reversing negative consequences of wood removal for lake communities and food web functioning is a long-lasting, complex process, special attention should be paid to the conservation of aquatic CWD and terrestrial vegetation. The maintenance of intact forests or planting native riparian trees, which provide CWD and submerged roots, as well as the sustainability of adequate amounts of wood in various stages of decay could potentially promote biodiversity and increase productivity in the littoral zone (Newbrey et al., 2005; Sass et al., 2006a; Smokorowski et al., 2006; Brauns et al., 2011). However, more detailed studies are still needed to establish the threshold at which an increase in the CWD density or complexity exerts positive effects on littoral biota. This should be combined with development of the consistent approach to measuring the complexity of CWD. Moreover, as local extinctions and reductions in biodiversity are rather a consequence of habitat fragmentation and decreased connectivity between species than just a function of net remaining habitat (Dobson et al., 2006), recognizing how the spatial arrangement of CWD influences biodiversity and connectivity between littoral populations, as well as predator-prey interactions, could be crucial for setting environmental goals. Such knowledge could also contribute to a reduction in emerging conflicts between the maintenance of high CWD densities in littoral zones and using lakes for navigation and recreational activities. Management strategies should be adapted to local conditions, regarding factors affecting the density, turnover and distribution of the littoral CWD, such as riparian land-use intensity, type of forest and lake morphometry. For instance, to ensure stocks of CWD above the minimum observed in undeveloped lakes, the building density should be defined regionally, as in various regions the lowest levels of CWD occur at different residential densities ranging from 12 to 20 buildings $\mathrm{km}^{-1}$ (Francis \& Schindler, 2006; Marburg et al., 2006). Given the high variability in CWD stocks and their distribution among lakes, more detailed studies are still needed to understand which combinations of factors typically control this variation in temperate lakes (Marburg et al., 2009). Finally, systematic large-scale research involving lakes dominated by different types of forest could clarify the contribution of littoral CWD to carbon sequestration and nutrient fluxes, especially in the face of changing climate and other human-induced disturbances.

Acknowledgments I thank Jarosław Kobak, Tomasz Kakareko (Nicolaus Copernicus University), Katya Kovalenko and two anonymous reviewers for valuable comments on the previous version of the manuscript. I am also grateful to Wiktoria Reich for preparing the figures.

Open Access This article is distributed under the terms of the Creative Commons Attribution 4.0 International License (http:// creativecommons.org/licenses/by/4.0/), which permits unrestricted use, distribution, and reproduction in any medium, provided you give appropriate credit to the original author(s) and the source, provide a link to the Creative Commons license, and indicate if changes were made.

\section{References}

Ahrenstorff, T. D., G. G. Sass \& M. R. Helmus, 2009. The influence of littoral zone coarse woody habitat on home range size, spatial distribution, and feeding ecology of largemouth bass (Micropterus salmoides). Hydrobiologia 623: 223-233.

Anderson, N. H., R. J. Steedman \& T. Dudley, 1984. Patterns of exploitation by stream invertebrates of wood debris (xylophagy). Verhandlungen der Internationalen Vereinigung für Theoretische und Angewandte Limnologie 22: 1847-1852.

Barwick, R. D., T. J. Kwak, R. Noble \& D. H. Barwick, 2004. Fish populations associated with habitat-modified piers and natural woody debris in Piedmont Carolina reservoirs. 
North American Journal of Fisheries Management 24: 1120-1133.

Biro, P. A., C. Beckmann \& M. S. Ridgway, 2008. Early microhabitat use by age 0 year brook charr Salvelinus fontinalis in lakes. Journal of Fish Biology 73: 226-240.

Bond, N. R., S. Sabater, A. Glaister, S. Roberts \& K. Vanderkruk, 2006. Colonisation of introduced timber by algae and invertebrates, and its potential role in aquatic ecosystem restoration. Hydrobiologia 556: 303-316.

Bowen, K. L., N. K. Kaushik \& A. M. Gordon, 1998. Macroinvertebrate communities and biofilm chlorophyll on woody debris in two Canadian oligotrophic lakes. Archiv für Hydrobiologie 141: 257-281.

Braccia, A. \& D. P. Batzer, 2008. Breakdown and invertebrate colonization of dead wood in wetland, upland, and river habitats. Canadian Journal of Forest Research 38: 2697-2704.

Brauns, M., X.-F. Garcia, M. T. Pusch \& N. Walz, 2007. Eulittoral macroinvertebrate communities of lowland lakes: discrimination among trophic states. Freshwater Biology 52: 1022-1032.

Brauns, M., B. Gücker, C. Wagner, X.-F. Garcia, N. Walz \& M. T. Pusch, 2011. Human lakeshore development alters the structure and trophic basis of littoral food webs. Journal of Applied Ecology 48: 916-925.

Carpenter, S. R., E. H. Stanley \& M. J. Vander Zanden, 2011. State of the world's freshwater ecosystems: physical, chemical, and biological changes. Annual Review of Environment and Resources 36: 75-99.

Christensen, D. L., B. R. Herwig, D. E. Schindler \& S. R. Carpenter, 1996. Impacts of lakeshore residential development on coarse woody debris in north temperate lakes. Ecological Applications 6: 1143-1149.

Collier, K. J. \& J. N. Halliday, 2000. Macroinvertebrate-wood associations during decay of plantation pine in New Zealand pumice-bed streams: stable habitat or trophic subsidy? Journal of the North American Benthological Society 19: 94-111.

Collier, K. J. \& B. J. Smith, 2003. Role of wood in pumice-bed streams II: breakdown and colonisation. Forest Ecology and Management 177: 261-276.

Couch, C. A. \& J. L. Meyer, 1992. Development and composition of the epixylic biofilm in a blackwater river. Freshwater Biology 27: 43-51.

Czarnecka, M., F. Pilotto \& M. T. Pusch, 2014. Is coarse woody debris in lakes a refuge or a trap for benthic invertebrates exposed to fish predation? Freshwater Biology 59: 2400-2412.

Dale, V. H., et al., 2001. Climate change and forest disturbances. BioScience 51: 723-734.

DeBoom, C. S. \& D. H. Wahl, 2013. Effects of coarse woody habitat complexity on predator-prey interactions of four freshwater fish species. Transactions of the American Fisheries Society 142: 1602-1614.

Dobson, A., et al., 2006. Habitat loss, trophic collapse, and the decline of ecosystem services. Ecology 87: 1915-1924.

Drury, D. M. \& W. E. Kelso, 2000. Invertebrate colonization of woody debris in coastal plain streams. Hydrobiologia 434: 63-72.

Dudley, T. \& N. H. Anderson, 1982. A survey of invertebrates associated with wood debris in aquatic habitats. Melanderia 39: 1-21.
Eggert, S. L. \& J. B. Wallace, 2007. Wood biofilm as a food resource for stream detritivores. Limnology and Oceanography 52: 1239-1245.

Everett, R. A. \& G. M. Ruiz, 1993. Coarse woody debris as a refuge from predation in aquatic communities. Oecologia 93: 475-486.

Flebbe, P. A., 1999. Trout use of woody debris and habitat in Wine Spring Creek, North Carolina. Forest Ecology and Management 114: 367-376.

France, R. I., 1997. Macroinvertebrate colonization of woody debris in Canadian shield lakes following riparian clearcutting. Conservation Biology 11: 513-521.

Francis, T. \& D. E. Schindler, 2006. Degradation of littoral habitats by residential development: woody debris in lakes of the Pacific Northwest and Midwest, United States. Ambio 35: 274-280.

Francis, T., D. E. Schindler, J. M. Fox \& E. Seminet-Reneau, 2007. Effects of urbanization on the dynamics of organic sediments in temperate lakes. Ecosystems 10: 1057-1068.

Gabel, F., X.-F. Garcia, M. Brauns, A. Sukhodolov, M. Leszinski \& M. T. Pusch, 2008. Resistance to ship-induced waves of benthic invertebrates in various littoral habitats. Freshwater Biology 53: 1567-1578.

Gaeta, J. W., G. G. Sass \& S. R. Carpenter, 2014. Droughtdriven lake level decline: effects on coarse woody habitat and fishes. Canadian Journal of Fisheries and Aquatic Sciences 71: 315-325.

Gennaretti, F., D. Arseneault \& Y. Bégin, 2014. Millennial stocks and fluxes of large woody debris in lakes of the North American taiga. Journal of Ecology 102: 367-380.

Glaz, P. N., Ch Nozais \& D. Arseneault, 2009. Macroinvertebrates on coarse woody debris in the littoral zone of a boreal lake. Marine and Freshwater Research 60: 960-970.

Golladay, S. W. \& R. L. Sinsabaugh, 1991. Biofilm development on leaf and wood surfaces in a boreal river. Freshwater Biology 25: 437-450.

Gurnell, A. M., 2003. Wood storage and mobility. In Gregory, S. V., K. L. Boyer \& A. M. Gurnell (eds.). The ecology and management of wood in world rivers. American Fisheries Society Symposium, Bethesda: 75-91.

Guyette, R. P. \& W. G. Cole, 1999. Age characteristics of coarse woody debris (Pinus strobus) in a lake littoral zone. Canadian Journal of Fisheries and Aquatic Sciences 56: 496-505.

Guyette, R. P., W. G. Cole, D. C. Dey \& R.-M. Muzika, 2002. Perspectives on the age and distribution of large wood in riparian carbon pools. Canadian Journal of Fisheries and Aquatic Sciences 59: 578-585.

Harmon, M. E., et al., 1986. Ecology of coarse woody debris in temperate ecosystems. Advances in Ecological Research 15: $133-302$.

Helmus, M. R. \& G. G. Sass, 2008. The rapid effects of a wholelake reduction of coarse woody debris on fish and benthic macroinvertebrates. Freshwater Biology 53: 1423-1433.

Howell, T. D., A. H. Arthington, B. J. Pusey, A. P. Brooks, B. Creese \& J. Chaseling, 2012. Responses of fish to experimental introduction of structural woody habitat in riffles and pools. Restoration Ecology 20: 43-55.

Jennings, M. J., E. E. Emmons, G. R. Hatzenbeler, C. Edwards \& M. A. Bozek, 2003. Is littoral habitat affected by residential development and land use in watersheds of 
Wisconsin lakes? Lake and Reservoir Management 19: 272-279.

Lawson, Z. J., J. W. Gaeta \& S. R. Carpenter, 2011. Coarse woody habitat, lakeshore residential development, and largemouth bass nesting behaviour. North American Journal of Fisheries Management 31: 666-670.

Lewin, W-Ch, N. Okun \& T. Mehner, 2004. Determinants of the distribution of juvenile fish in the littoral area of a shallow lake. Freshwater Biology 49: 410-424.

Lindroth, A., F. Lagergren, A. Grelle, L. Klemedtsson, O. Langvall \& P. Weslien, 2009. Storms can cause Europewide reduction in forest carbon sink. Global Change Biology 15: 346-355.

Loreau, M., et al., 2001. Biodiversity and ecosystem functioning: current knowledge and future challenges. Science 294: 804-808.

Mallory, E. C., M. S. Ridgway, A. M. Gordon \& N. K. Kaushik, 2000. Distribution of woody debris in a small headwater lake, central Ontario, Canada. Archiv für Hydrobiologie 148: 587-606.

Marburg, A. E., M. G. Turner \& T. K. Kratz, 2006. Natural and anthropogenic variation in coarse wood among and within lakes. Journal of Ecology 94: 558-568.

Marburg, A. E., S. B. Bassak, T. K. Kratz \& M. G. Turner, 2009. The demography of coarse wood in north temperate lakes. Freshwater Biology 54: 1110-1119.

Melillo, J. M., R. J. Naiman, J. D. Abet \& K. N. Eshleman, 1983. The influence of substrate quality and stream size on wood decomposition dynamics. Oecologia 58: 281-285.

Newbrey, M. G., M. A. Bozek, M. J. Jennings \& J. E. Cook, 2005. Branching complexity and morphological characteristics of coarse woody structure as lacustrine fish habitat. Canadian Journal of Fisheries and Aquatic Sciences 62: 2110-2123.

O'Connor, N. A., 1991. The effects of habitat complexity on the macroinvertebrates colonising wood substrates in a lowland stream. Oecologia 85: 504-512.

Palmer, M. A., H. L. Menninger \& E. Bernhardt, 2010. River restoration, habitat heterogeneity and biodiversity: a failure of theory or practice? Freshwater Biology 55: 205-222.

Pereira, C. R. D., N. H. Anderson \& T. Dudley, 1982. Gut content analysis of aquatic insects from wood substrates. Melanderia 39: 23-33.

Roth, B. M., I. C. Kaplan, G. G. Sass, P. T. Johnson, A. E. Marburg, A. C. Yannarell, T. D. Havlicek, T. V. Willis, M. G. Turner \& S. R. Carpenter, 2007. Linking terrestrial and aquatic ecosystems: the role of woody habitat in lake food webs. Ecological Modelling 203: 439-452.

Sass, G. G., J. F. Kitchell, S. R. Carpenter, T. R. Hrabik, A. E. Marburg \& M. G. Turner, 2006a. Fish community and food web responses to a whole-lake removal of coarse woody habitat. Fisheries 31: 321-330.

Sass, G. G., C. M. Gille, J. T. Hinke \& J. F. Kitchell, 2006 b. Whole-lake influences of littoral structural complexity and prey body morphology on fish predator-prey interactions. Ecology of Freshwater Fish 15: 301-308.
Sass, G. G., S. R. Carpenter, J. W. Gaeta, J. F. Kitchell \& T. D. Ahrenstorff, 2012. Whole-lake addition of coarse woody habitat: response of fish populations. Aquatic Sciences 74: 255-266.

Schindler, D. E., S. I. Geib \& M. R. Williams, 2000. Patterns of fish growth along a residential development gradient in north temperate lakes. Ecosystems 3: 229-237.

Schneider, K. N. \& K. O. Winemiller, 2008. Structural complexity of woody debris patches influences fish and macroinvertebrate species richness in a temperate floodplain-river system. Hydrobiologia 610: 235-244.

Scholz, O. \& P. Boon, 1993. Biofilm development and extracellular enzyme activities on wood in billabongs of southeastern Australia. Freshwater Biology 30: 359-368.

Sinsabaugh, R. L., S. W. Golladay \& A. E. Linkins, 1991. Comparison of epilithic and epixylic biofilm development in a boreal river. Freshwater Biology 25: 179-187.

Smokorowski, K. E., T. C. Pratt, W. G. Cole, L. J. Mceachern \& E. C. Mallory, 2006. Effects on periphyton and macroinvertebrates from removal of submerged wood in three Ontario lakes. Canadian Journal of Fisheries and Aquatic Sciences 63: 2038-2049.

Spänhoff, B. \& E. I. Meyer, 2006. Breakdown rates of wood in streams. Journal of the North American Benthological Society 23: 189-197.

Spänhoff, B., Ch Reuter \& E. I. Meyer, 2006. Epixylic biofilm and invertebrate colonization on submerged pine branches in a regulated lowland stream. Archiv für Hydrobiologie 165: 515-536.

Steedman, R. J. \& N. H. Anderson, 1985. Life history and ecological role of the xylophagous aquatic beetle, Lara avara LeConte (Dryopoidea: Elmidae). Freshwater Biology 15 : 535-546.

Tank, J. L. \& W. K. Dodds, 2003. Nutrient limitation of epilithic and epixylic biofilms in ten North American streams. Freshwater Biology 48: 1031-1049.

Tank, J. L. \& M. J. Winterbourn, 1996. Biofilm development and invertebrate colonization of wood in four New Zealand streams of contrasting pH. Freshwater Biology 34: 303-315.

Vadeboncoeur, Y.\& D. M. Lodge, 2000. Periphyton production on wood and sediment: substratum-specific response to laboratory and whole-lake manipulations. Journal of the North American Benthological Society 19: 68-81.

Vadeboncoeur, Y., J. Kalff, K. Christoffersen \& E. Jeppesen, 2006. Substratum as a driver of variation in periphyton chlorophyll and productivity in lakes. Journal of the North American Benthological Society 25: 379-392.

Ward, G. M. \& N. G. Aumen, 1986. Woody debris as a source of fine particulate organic matter in coniferous forest stream ecosystems. Canadian Journal of Fisheries and Aquatic Sciences 43: 1635-1642.

Weedon, J. T., W. K. Cornwell, J. H. C. Cornelissen, A. E. Zanne, Ch Wirth \& D. A. Coomes, 2009. Global metaanalysis of wood decomposition rates: a role for trait variation among tree species. Ecology Letters 12: 45-56. 